See discussions, stats, and author profiles for this publication at: https://www.researchgate.net/publication/283213526

\title{
Assessing the influence of geographic distance in parasite communities of an
} exotic lizard

Article in Acta Parasitologica · January 2016

DOI: 10.1515/ap-2016-0018

\section{CITATIONS}

4

8 authors, including:

Castiele Bezerra

Universidade Federal do Ceará

17 PUBLICATIONS 79 CITATIONS

SEE PROFILE

Gabriela Cavalcante de Melo

Pontifícia Universidade Católica de Minas Gerais

6 PUBlications 18 Citations

SEE PROFILE
311

Luan T Pinheiro

Pontifícia Universidade Católica de Minas Gerais

8 PUBlications 30 Citations

SEE PROFILE

Djan Zanchi

Universidade Federal do Ceará

16 PUBLICATIONS 62 CITATIONS

SEE PROFILE

Some of the authors of this publication are also working on these related projects:

Modelling terrestrial biodiversity in the Cape Verde islands: combining ecogeographical information with molecular markers View project

PATHOSPILL: using an integrative approach to investigate the consequences of pathogen spill-over between wild and farmed fish species in a key estuarine habitat View project 


\title{
Assessing the influence of geographic distance in parasite communities of an exotic lizard
}

\author{
Castiele Holanda Bezerra ${ }^{1,2,{ }^{*}}$, Luan Tavares Pinheiro ${ }^{2,3}$, Gabriela Cavalcante de Melo ${ }^{2,3}$, \\ Djan Zanchi-Silva ${ }^{1,2}$, Murilo de Souza Queiroz ${ }^{4}$, Luciano Alves dos Anjos ${ }^{4}$, \\ David James Harris ${ }^{5}$ and Diva Maria Borges-Nojosa ${ }^{1,2}$
}

\author{
${ }^{1}$ Programa de Pós-Graduação em Ecologia e Recursos Naturais, Universidade Federal do Ceará, Fortaleza, 60455-760, Ceará, Brazil; \\ ${ }^{2}$ Núcleo Regional de Ofiologia, Universidade Federal do Ceará, Fortaleza, 60455-760, Ceará, Brazil; \\ ${ }^{3}$ Programa de Pós-Graduação em Biologia de Vertebrados da Pontifícia Universidade Católica de Minas Gerais. Av. Dom José Gaspar No500, \\ Coração Eucarístico, 30535-610, Belo Horizonte, Minas Gerais, Brazil; ${ }^{4}$ UNESP - Universidade Estadual Paulista, \\ Campus de Ilha Solteira, Faculdade de Engenharia, Departamento de Biologia e Zootecnia, Ilha Solteira, São Paulo, Brazil; \\ ${ }^{5}$ CIBIO Research Centre in Biodiversity and Genetic Resources, InBIO, Universidade do Porto, Campus Agrário de Vairão, \\ Padre Armando Quintas, № 7, 4485-661 Vairão, Vila do Conde, Portugal
}

\begin{abstract}
The decay of similarity between biological communities with increasing geographical distance is a well-established pattern in ecology, but there are more complex factors acting on host population connections that influence this association for parasite communities, such as parasites' colonization ability and degree of connectivity between host populations. Here we aim to determine the helminth communities associated with different populations of the host lizard Hemidactylus mabouia, testing if the similarity of parasite communities decreases as the distance between them increases. For this, we collected samples of lizard populations in seven sites from Northeastern coast of Brazil and identified parasite species of helminths and pentastomids in each host, calculated the Sørensen indices of presence/absence and abundance of each pair of communities and related them to the geographical distance. We did not find a relationship of decaying similarity with increasing distance between the parasite communities of the host populations. This can be explained by factors such as the characteristics of the contact between the host populations, and by modes of transmission of most parasite species. Furthermore, it may be related to the exotic nature of the host in Brazil so that parasite communities have not reached equilibrium.
\end{abstract}

\section{Keywords}

Helminths, Hemidactylus mabouia, parasite ecology, species turnover

\section{Introduction}

Understanding the distribution patterns of individuals and species across multiple spatial scales is important because it provides crucial information to describe the forces that structure and maintain biological diversity (Harte et al. 2005). The decay of similarity between biological communities with increasing geographical distance is a well-established pattern in ecology (Ricklefs 1987; Nekola and White 1999; Soininen et al. 2007). Parasite communities are good models for such studies, because their moderate richness of species in a welldelimited habitat (the hosts) makes it possible to sample all the species (Poulin 2003).
Several studies have been performed regarding the relationship between distance and the similarity of parasite communities in various host taxa, such as mammals (Poulin 2003; Krasnov et al. 2005; Brouat and Duplantier 2007; Vinarski et al. 2007), fishes (Poulin and Morand 1999; Poulin 2003; Karvonen and Valtonen 2004; Fellis and Esch 2005; Oliva and González 2005; Karvonen and Valtonen 2009), molluscs (Thieltges et al. 2009) and birds (Locke et al. 2011). In several cases a decay in similarity with distance was observed, although many other factors, such as the type of habitat and the host's dispersal ability (Poulin 2003; Soininen et al. 2007), as well as time (Hubbell 2001) are also important. Clearly therefore, for broader generalizations there is a need to test other host taxa, for example reptiles. 
Contrary to what happens in free-living species, the environmental similarity for parasites involves not only the physical environment, but also the environment resulting from the species composition of the parasite community in the host (Vinarski et al. 2007), or even the intraspecific geographical variation in the host's response to parasite attacks (Ardia 2005). In general, the parasites' dispersal potential is much smaller than their hosts' dispersal potential (Poulin 2003), because parasites usually depend on their hosts for dispersion. The similarity of parasite communities between host populations is also affected, among other things, by the parasites' colonization ability and by the vagility and the degree of connectivity between host populations, both in the present and as a reflection of the past (Brouat and Duplantier 2007; Karvonen and Valtonen 2009).

Generally, the composition similarity of parasite communities decays exponentially as the geographical distance between the host populations increases. However, this is not a rule for all species, since there is significant temporal and spatial variation, as well as short-term effects and local processes that are associated with the structure of parasite communities that bar the generality of conclusions reached for individual systems (Poulin 2003; Karvonen and Valtonen 2009).
Hemidactylus mabouia (Moreau de Jonnès, 1818) (Squamata, Gekkonidae) is a lizard species widely distributed in Africa (Carranza and Arnold 2006), where it is native, and in America (Vanzolini 1978; Baldo et al. 2008; Rocha et al. 2011), where it is exotic. In Brazil, H. mabouia is well established in anthropic environments, but it is also found in natural ones (Rocha et al. 2011). Aspects of its ecology have been well elucidated (Vitt 1995; Rocha and Anjos 2007; Anjos and Rocha 2008), as well as studies concerning its parasites (Anjos et al. 2005; Ávila and Silva 2010). However, parasite studies of H. mabouia only described the composition of parasite species from isolated populations. Since this lizard species has a wide distribution, relative abundance and several ecological aspects are well-known, it is a good model organism for ecological studies.

Since biological communities tend to be more similar as the distance between them decreases, we expected to find decay in similarity with the distance of parasite component communities in populations of $H$. mabouia. Therefore, our objective was to investigate how geographical distance influences the similarity of parasite communities (helminths and pentastomids) of the exotic lizard H. mabouia, and to compare the patterns observed with those determined in other host groups.

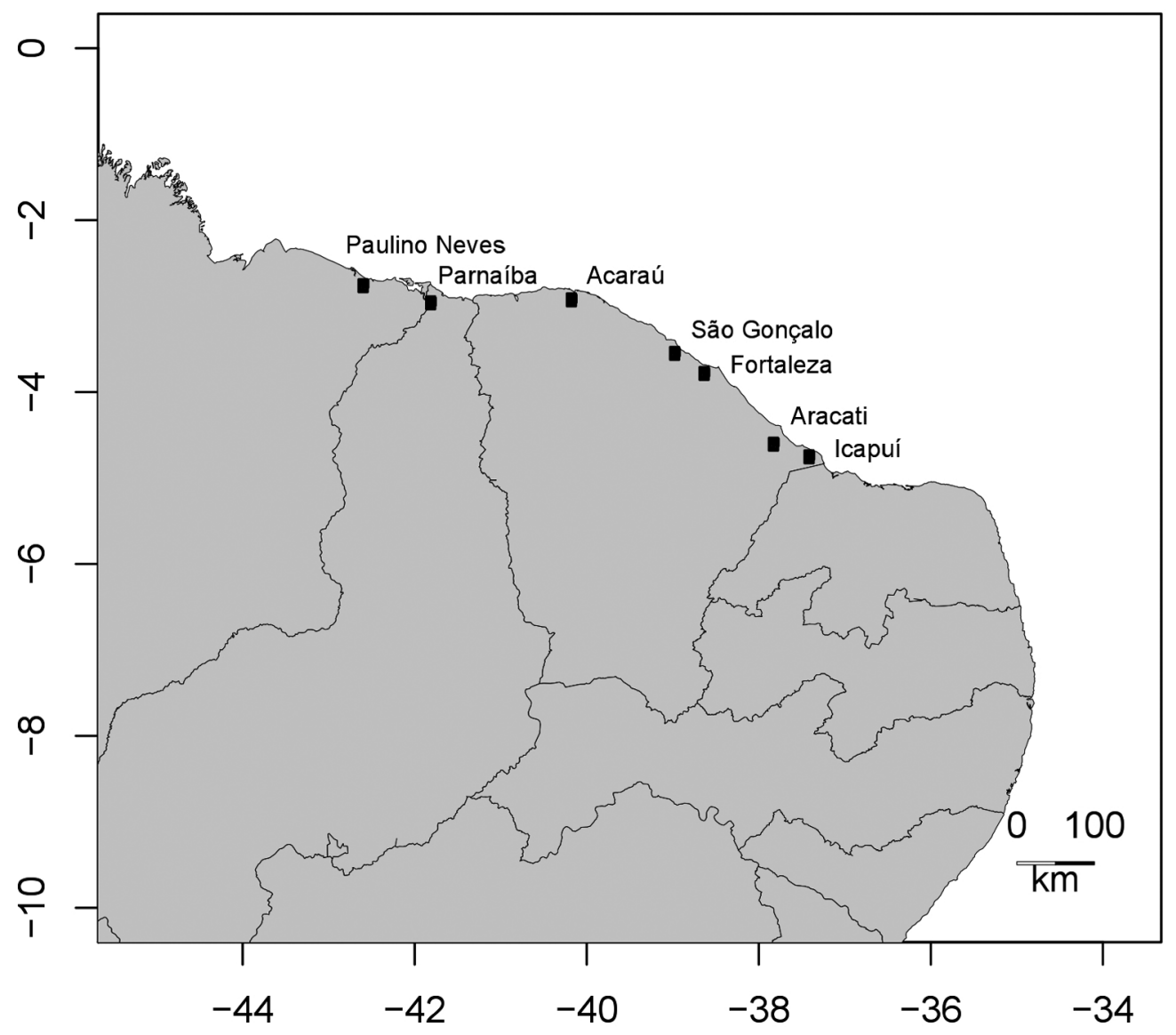

Fig. 1. Map of the Northern Coast of Northeast Brazil with the sampled sites of the lizard host populations Hemidactylus mabouia (Source: R Program) 


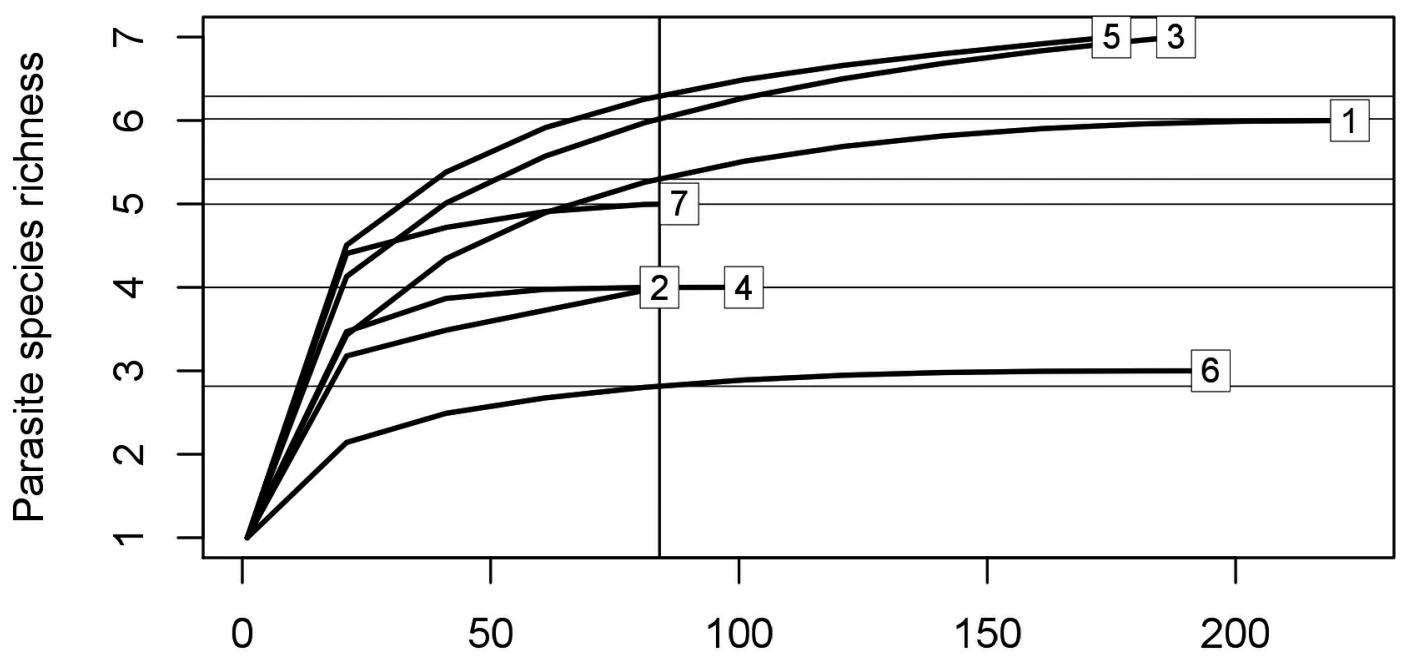

Number of parasite individuals

Fig. 2. Rarefaction curve of parasite communities of the lizard host Hemidactylus mabouia from sampling sites: 1-Paulino Neves, 2-Parnaíba, 3-Acaraú, 4-São Gonçalo, 5-Fortaleza, 6-Aracati, 7-Icapuí (Source: R Program)

\section{Material and Methods}

We collected lizards in urban areas from seven towns on the North East coast of Brazil (Fig. 1), between March and June 2013, the wet season. The linear distances between the towns vary from 48 to $619 \mathrm{~km}$. This study area is a biogeographically complex region, with species from several Brazilian biomes, including Caatinga and Cerrado savanna, Atlantic and Amazon rainforests and vegetation from restinga, typical of the Brazilian coast (Ab'Saber 2002). Annual rainfall ranges from 986 to $1222 \mathrm{~mm} /$ year and average temperature from 26 to $27.5^{\circ} \mathrm{C}$ across all collection sites (Santos-Filho 2009; Castro et al. 2012; Oliveira and Frota 2011). We performed the lizard collections in the same season, in places with similar climatic and vegetation features to reduce the effects from other factors that may affect the composition of parasite communities aside from geographical distance.

We collected lizards manually or with a rubber band, between 18.00 and $05.00 \mathrm{~h}$. Individuals that were not killed during capture were anesthetized with Ketamina and euthanized with potassium chloride (CFMV 2002). We preserved the lizards in formaldehyde and deposited them in the 'Coleção de Herpetologia do Núcleo Regional de Ofiologia da Universidade Federal do Ceará (CHUFC)'.

To obtain parasites, we dissected the lizards and inspected their organs (stomach, intestines, lungs, liver, gall bladder and body cavity) for endoparasites. We removed the parasites and preserved them in ethanol. Then, we identified the helminths and pentastomids and deposited them in 'Coleção Helmintológica do Departamento de Parasitologia do Instituto de Biociências (CHIBB), Unesp, campus de Botucatu'.
We used terms of parasite ecology from Bush, Lafferty, Lotz and Shostak (1997). We used the rarefaction method to test if species richness was biased by sampling effort (Gotelli and Colwell 2001). We estimated the prevalence and the mean intensity of infection for each parasite species and estimated overall prevalence, overall mean intensity, overall richness, overall diversity (Shannon index) and mean diversity (Brillouin index) for each sampled community (site). The Shannon and Brillouin indices were estimated using PAST (Hammer et al. 2001).

We used two indices to determine the similarity between the parasite communities. First we used the Sørensen index for presence/absence data to measure the similarity in composition of parasite species, with $C_{s}=2 j /(a+b)$, where $j$ is the number of parasite species common between the two host populations; and $a$ and $b$ are the numbers of species found in the first and in the second populations, respectively. Second, we used the Sørensen quantitative index to measure the similarity in abundance of parasite species between populations, with $C_{N}=2 j_{N} /\left(a_{N}+b_{N}\right)$, where $a_{N}$ is the sum of the abundance means of parasite species in the first host population, $b_{N}$ is the sum of the abundance means of parasite species in the second host population and $j_{N}$ is the sum of the lowest of the two species abundances of the two host populations (Magurran 1988). Both indices ranges from 0 to 1 , where 0 represents two totally different communities and 1 represents two totally similar communities. We used the software program EstimateS (Colwell 2013) to measure these indices.

In order to analyze the effect of the geographical distance on the similarity of communities, we performed linear regression analyzes with the distance between each pair of sampled sites and their qualitative and quantitative similarities (presence/absence and abundance, respectively) of parasite com- 
Table I. Parasite species of the lizard host Hemidactylus mabouia. Kind of transmission: direct (D) and indirect (I). Site of collection: 1-Paulino Neves, 2-Parnaíba, 3-Acaraú, 4-São Gonçalo, 5-Fortaleza, 6-Aracati, 7-Icapuí. Prevalence (P). Mean Intensity of Infection $(\mathrm{MII}) \pm$ Standard Deviation (SD). Infection Sites (IS): $\mathrm{S}=$ stomach, $\mathrm{SI}=$ small intestine, $\mathrm{LI}=$ large intestine, $\mathrm{BC}=$ body cavity, $\mathrm{LU}=$ lung, $\mathrm{LI}=$ liver, $\mathrm{GB}=$ gall bladder

\begin{tabular}{|c|c|c|c|c|c|}
\hline Species & Transmission & Site & $\mathbf{P}(\%)$ & $\mathrm{MII} \pm \mathrm{SD}$ (range) & IS \\
\hline \multicolumn{6}{|l|}{ NEMATODA } \\
\hline Parapharyngodon alvarengai (Freitas, 1956) & $\mathrm{D}$ & All & 32.15 & $2.43 \pm 2.15(1-11)$ & SI, LI \\
\hline Physaloptera retusa (Rudolphi, 1819) & I & $1,3,4,5,7$ & 6.16 & $3.21 \pm 4.21(1-10)$ & S,SI,LI \\
\hline Skrjabinodon sp. (Inglis, 1968) & $\mathrm{D}$ & 5 & 1.32 & $11.33 \pm 1.19(1-30)$ & LI \\
\hline \multicolumn{6}{|l|}{ TREMATODA } \\
\hline $\begin{array}{l}\text { Digenea: } \\
\text { Platynosomum sp. (Looss, 1907) and Paradistomum sp. } \\
\text { (Kossack, 1910) } \\
\text { CESTODA }\end{array}$ & I & All & 31.71 & $9.4 \pm 11.78(1-59)$ & GB,SI,BC \\
\hline Oochoristica sp. (Lühe, 1898) & I & $1,2,3,4,5,7$ & 6.16 & $1.28 \pm 2.75(1-5)$ & SI \\
\hline Plerocercoid larvae & I & $3,5,6,7$ & 2.2 & $6.4 \pm 8.53(1-21)$ & BC,LI \\
\hline Proteocephalidae (La Rue, 1911) & I & 3 & 0.88 & $1 \pm 0(1)$ & SI \\
\hline \multicolumn{6}{|l|}{ ACANTHOCEPHALA } \\
\hline Centrorhynchidae (larvae) (Van Cleave, 1916) & I & 1,2 & 1.76 & $3.75 \pm 1.7(2-6)$ & $\mathrm{BC}$ \\
\hline \multicolumn{6}{|l|}{ PENTASTOMIDA } \\
\hline Raillietiella frenatus (Ali, Riley and Self, 1981) & I & $1,3,5$ & 3.96 & $3.33 \pm 3.5(1-11)$ & LU \\
\hline
\end{tabular}

munities. Additionally, we performed a cluster analysis with the parasite communities from each site and used the Sørensen presence/absence index as a similarity measure using PAST (Hammer et al. 2001). Statistical analyses were performed using the R platform (R Development Core Team 2012).

\section{Results}

From all 227 lizards collected, we registered one pentastomid species and nine helminth species, including one acanthocephala, two digenea, three cestodes and three nematodes (Table I). Although we could identify the digenean species, the identification of most digenean specimens was not possible because of methodological procedures and thus we will just refer to the group Digenea. Parapharyngodon alvarengai was the most prevalent species, present in $32.15 \%$ of the lizards, and Digenea was the most abundant taxon, with a mean intensity of $9.4 \pm 11.78$ individuals per lizard and representing $63.9 \%$ of all parasite specimens found.

The rarefaction curves shows tendency to established lines for all sampling sites, indicating sampling sufficiency (Fig. 2), hence it is unlikely that the sampling effort has biased the results. The parasite community with the largest Shannon and Brillouin indices was from the host population from Icapuí, which had the third lowest richness and the lowest overall prevalence (Table II), highlighting that a greater number of infected lizards does not necessarily represent a greater number of parasite species.

The most similar parasite communities are those from the host populations from Icapuí and São Gonçalo, which are separated by more than $200 \mathrm{~km}$ (Figs 1 and 3). The community from the host population from Aracati was the most distant in terms of similarity of all communities, possibly associated with it having the lowest richness, total and mean diversities (Table II).

Table II. Infection patterns and diversity indices of parasite communities of the host Hemidactylus mabouia among sampled sites: 1-Paulino Neves, 2-Parnaíba, 3-Acaraú, 4-São Gonçalo, 5-Fortaleza, 6-Aracati, 7-Icapuí

\begin{tabular}{|c|c|c|c|c|c|}
\hline Site (n) & $\begin{array}{c}\text { Overall prevalence } \\
(\%)\end{array}$ & $\begin{array}{l}\text { Mean intensity } \\
\text { of Infection }\end{array}$ & Richness & $\begin{array}{l}\text { Diversity } \\
\text { (Shannon) }\end{array}$ & $\begin{array}{c}\text { Mean diversity } \\
\text { (Brillouin) }\end{array}$ \\
\hline $1(30)$ & 53.3 & $14.1 \pm 15.5$ & 6 & 0.821 & 0.779 \\
\hline $2(30)$ & 43.3 & $6.4 \pm 9.3$ & 4 & 0.847 & 0.786 \\
\hline $3(31)$ & 54.8 & $11 \pm 11.9$ & 7 & 1.095 & 1.038 \\
\hline $4(34)$ & 47.0 & $6.3 \pm 4.1$ & 4 & 1.038 & 0.979 \\
\hline $5(39)$ & 66.6 & $6.7 \pm 6.7$ & 7 & 1.363 & 1.299 \\
\hline $7(32)$ & 37.5 & $7.3 \pm 10.2$ & 5 & 1.436 & 1.348 \\
\hline
\end{tabular}




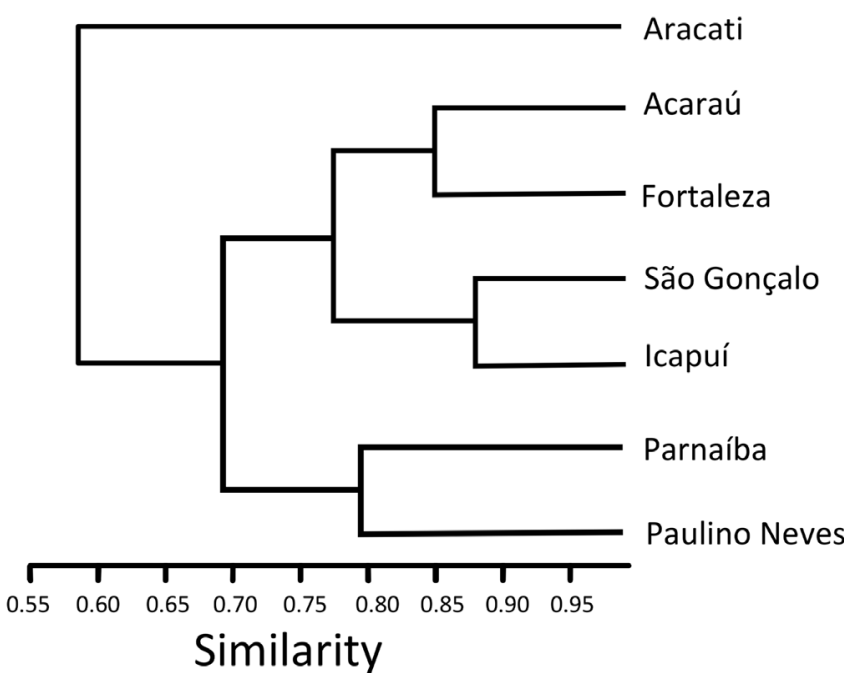

Fig. 3. Cluster analysis of the parasite communities from each sampling site of the lizard host Hemidactylus mabouia according to their qualitative similarity (presence/absence) (Sørensen index) (Source: PAST)

We did not find a relationship between geographical distance and the similarity of the parasite communities, neither in presence/absence similarity $\left(\mathrm{R}^{2}=0.025 ; \mathrm{F}_{1,19}=1.52 ; \mathrm{p}=\right.$ $0.23)$ nor in abundance similarity $\left(\mathrm{R}^{2}=-0.052 ; \mathrm{F}_{1,19}=0.003\right.$; $\mathrm{p}=0.95$ ) (Fig. 4). Since Karvonen and Valtonen (2009) suggest that patterns of organization of communities may be masked by the most abundant species, we performed the regression tests excluding first the most abundant taxon ( $\mathrm{Di}-$ genea) and then the two most abundant taxa (Digenea and $P$. alvarengai) but this did not change the results.

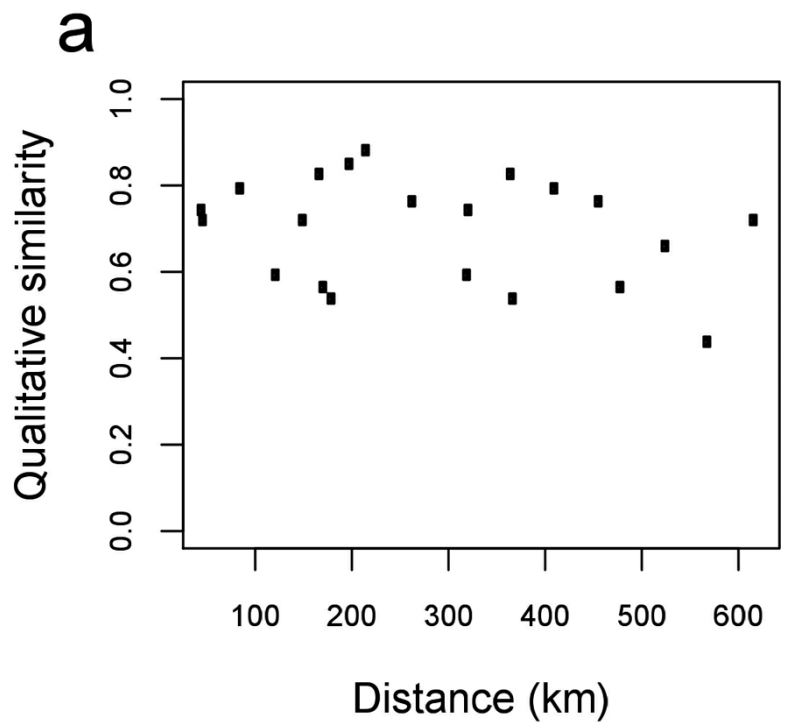

\section{Discussion}

Populations of exotic species usually have lower numbers of parasite species than native populations (Torchin et al. 2003), because parasites are often left behind during the course of the host range expansion (Phillips et al. 2010), and this is cited as one of the reasons for the success of many introduced species (Keane and Crawley 2002). Contrary to what was expected for an exotic species, H. mabouia has about the same number of parasite species compared to native populations of other Brazilian lizard species (Menezes et al. 2004; Anjos et al. 2011; Barreto-Lima et al. 2011; Anjos et al. 2012).

The similarity in composition of parasite communities presents an exponential decrease as the distance increases in many host species (Poulin 2003). However, many other factors play a role, which explains why various other studies apart from this one also did not find this correlation (Felis and Esch 2005; Oliva and González 2005). Hemidactylus mabouia is an exotic species with a great power of dispersion and colonization (Baldo et al. 2008; Rödder et al. 2008; Rocha et al. 2011) and that already has about 20 metazoan endoparasite species (helminths and pentastomids) registered only in South America (Anjos et al. 2005; Ávila et al. 2012). Most of the parasite species recorded here are generalists, parasitizing other native hosts (Ávila and Silva 2010), except the pentastomid Raillietiella frenatus, which has an African origin and probably followed the colonization pattern of the host (Anjos et al. 2008). Similar results were founded in an invasive species in Australia, H. frenatus, where the parasite fauna was predominantly composed by generalist species, but with one species that did not occur in the invaded area (Barton 2015). Knowing that H. mabouia has a parasitic fauna composed mainly of generalist species, which is charac-

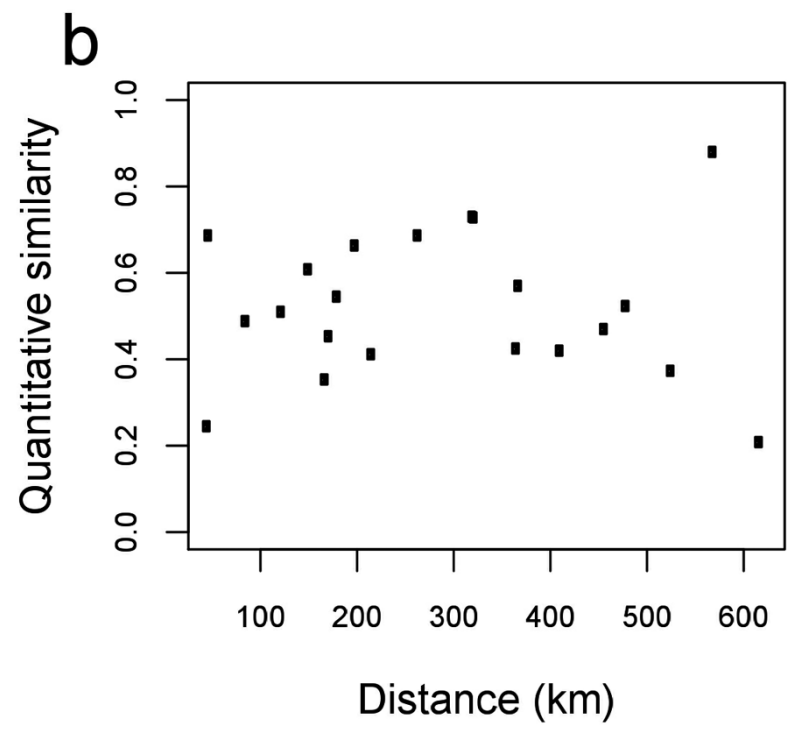

Fig. 4. Relationship between the Sørensen indices of qualitative similarity (presence/absence) a and quantitative similarity (abundance) $\mathbf{b}$ and the geographical linear distances between each pair of sampled sites for the parasite communities of the lizard host Hemidactylus mabouia (Source: R Program) 
teristic of exotic host species, it should be influenced by parasite communities of other host species from each site and this can possibly mask the effect of the distance in the similarity of parasite communities in this host species.

Parasite communities dominated by direct life cycle species provide important information about the spatial dynamics of the contact between hosts (Biek et al. 2006), where the host dispersal may be the main determinant of the spatial variation of the parasite communities' composition, features that may lead to a distance decay of similarity. However, in the present study, most parasite species found has indirect transmission, which involves more than one host species (Table I). In this case, the parasite communities' composition may be more influenced by other factors (that have more influence in other stages of the parasite's life cycle) rather than by the contact between H. mabouia populations. Furthermore, the expansion of H. mabouia into this region of Brazil is recent. Exactly how this expansion took place is also unknown, although exotic Hemidactylus in North American expand rapidly through a mix of jump and diffusion dispersal (Locey and Stone 2006). This may well obscure any simple correlation between similarity in parasites and distance, making it likely that other exotic hosts will also not demonstrate this pattern. Furthermore, the speed of the spread may mean that parasite communities are not yet in equilibrium. With time, more parasite species may be acquired that may alter the current findings.

Brouat and Duplantier (2007) proposed two explanations for the absence of the distance decay of similarity in parasite communities in a mammal species (Mastomys natalensis) that lives in anthropic environments. One possibility is that the habitat fragmentation for this species makes the movement of individuals between the populations difficult. Another is that those individuals that disperse have little or no parasites, avoiding the transmission of parasites between populations and masking the effect of the distance. The first hypothesis has some congruencies with this study. Like $M$. natalensis, $H$. mabouia is found in urban areas and the population connectivity of this lizard may be more dependent on anthropogenic flow between towns, with the lizards transported passively, rather than active dispersal by itself.

On the other hand, the second hypothesis seems less likely over the geographic distances involved. Juveniles inside populations do have greater tendencies to disperse, induced mainly by aggressive interactions with larger individuals (Bonfiglio et al. 2006) and an ontogenetic spatial differentiation in habitat use was observed in populations of this study (Bezerra et al. unpublished data). Considering that juveniles usually have lower infection indices than adults (Poulin 1997), the greater dispersal of juveniles may result in a low rate of parasite dispersal through diffusion, but jump dispersals (Locey and Stone 2006), such as those between cities, would be unaffected.

Environmental differences between two sites will affect the similarity in their parasite communities regardless of the geographical distance (Poulin et al. 2011a,b). Although we did not measure the environmental variables in each sam- pled site, they are all in the same latitudinal range, in the Northern Coast of Northeast Brazil, and have similar climatic characteristics, which should minimized the effects of environmental differences in the parasite communities of $H$. mabouia. However, it would be interesting to further test this, by comparing the diet of different populations to verify if it varies, and also to verify if dietary similarities reflect parasite community resemblance.

In general, the absence of a relation of distance decay of similarity in parasite communities in the host $H$. mabouia may be explained by several factors, many of which are associated with the exotic nature of the host species. Assessment of other introduced species will therefore be useful in refining the general patterns and expectations behind this relationship.

Acknowledgments. This study was supported by CAPES masters scholarship to Castiele $\mathrm{H}$. Bezerra during time of this research, $\mathrm{CNPq}$ postdoctoral fellowship (Process No. 201962/2010-1) to D.M. Borges-Nojosa and supported by project (Process No. 309617/20120), Fundação de Amparo à Pesquisa do Estado de São Paulo, FAPESP to support project (2012/20978-2) to Luciano A. Anjos. The Brazilian foundation Instituto Chico Mendes de Conservação da Biodiversidade (ICMBio) granted collect licence No 36614-3. Thanks colleagues from NUROF-UFC who help with the field work.

\section{References}

Ab'Sáber A.N. 2001. Litoral do Brasil. Metalivros, São Paulo, Brazil, 281pp

Anjos L.A., Rocha C.F.D., Vrcibradic D., Vicente J.J. 2005. Helminths of the exotic lizard Hemidactylus mabouia from a rock outcrop area in southeastern Brazil. Journal of Helminthology, 79, $307-$ 313. DOI:http://dx.doi.org/10.1079/JOH2005288

Anjos L.A., Almeida W.O., Vasconcellos A., Freire E.M.X., Rocha C.F.D. 2008. Pentastomids infecting an invader lizard, Hemidactylus mabouia (Gekkonidae) in northeastern Brazil. Brazilian Journal of Biology, 68, 611-615. DOI: http://dx.doi.org/ 10.1590/S1519-69842008000300019

Anjos L.A., Rocha C.F.D. 2008. The Hemidactylus mabouia Moreau De Jonnès, 1818 (Gekkonidae) lizard: an invasive alien species broadly distributed in Brazil. Natureza \& Conservação, 6, 196-207

Anjos L.A., Bezerra C.H., Passos D.C., Zanchi D., Galdino C.A.B. (2011). Helminth fauna of two gekko lizards, Hemidactylus agrius and Lygodactylus klugei (Gekkonidade), from caatinga biome, northeastern Brazil. Neotropical Helminthology, 5, 285-290

Anjos L.A., Ávila R.W., Ribeiro S.C., Almeida W.O., Silva R.J. 2012. Gastrointestinal nematodes of the lizard Tropidurus hispidus (Squamata, Tropiduridae) from a semi-arid region of northeastern Brazil. Journal of Helminthology, 87, 443-449. DOI: http://dx.doi.org/10.1017/S0022149X12000491

Ardia D.R. 2005. Tree swallows trade off immune function and reproductive effort differently across their range. Ecology, 86, 2040-2046. DOI: http://dx.doi.org/10.1890/04-1619

Ávila R.W., Anjos L.A., Ribeiro S.C., Morais D.H., Silva R.J., Almeida W.O. 2012. Nematodes of lizards (Reptilia: Squamata) from caatinga biome, northeastern Brazil. Comparative Parasitology, 79, 56-63. DOI: http://dx.doi.org/10.1654/4518.1 
Ávila R.W., Silva R.J. 2010. Checklist of helminths from lizards and amphisbaenians (Reptilia, Squamata) of South America. The Journal of Venomous Animals and Toxins including Tropical Diseases, 16, 543-572. DOI: http://dx.doi.org/10.1590/S167891992010000400005

Baldo D., Borteiro C., Brusquetti F., García J.E., Prigioni C. 2008. Reptilia, Gekkonidae, Hemidactylus mabouia, Tarentola mauritanica: distribution extension and anthropogenic dispersal. Check List, 4, 434-438

Barreto-Lima A.F., Toledo G.M., Anjos L.A. 2011. The nematode community in the Atlantic rain Forest lizard Enyalius perditus Jackson, 1978 from south-eastern Brazil. Journal of Helminthology, 86, 395-400. DOI: http://dx.doi.org/10.1017/ S0022149X11000599

Barton D.P. 2015. Helminth parasites of the introduced Asian House Gecko (Hemidactylus frenatus) (Gekkonidae), in the Northern Territory, Australia. Northern Territory Naturalist, 26, 44-55

Biek R., Drummond A.J., Poss M. 2006. A virus reveals population structure and recent demographic history of its carnivore host. Science, 311, 538-541. DOI: 10.1126/science. 1121360

Bonfiglio F., Balestrin R.L., Cappellari L.H. 2006. Diet of Hemidactylus mabouia (Sauria, Gekkonidae) in urban area of Southern Brazil. Biociências, 14, 107-111

Brouat C., Duplantier J.M. 2007. Host habitat patchiness and the distance decay of similarity among gastro-intestinal nematode communities in two species of Mastomys (southeastern Senegal). Oecologia, 152, 715-720. DOI: http://dx.doi.org/10. 1007/s00442-007-0680-8

Bush A.O., Lafferty K.D., Lotz J.M., Shostak A.W. 1997. Parasitology meets ecology on its own terms: Margolis et al. revisited. The Journal of Parasitology, 83, 575-583

Carranza S., Arnold E.N. 2006. Systematics, biogeography and evolution of Hemidactylus geckos (Reptilia, Gekkonidae) elucidated using mitochondrial DNA sequences. Molecular Phylogenetics and Evolution, 38, 531-545. DOI: http://dx. doi.org/10.1016/j.ympev.2005.07.012

Castro A.S.F., Moro M.F., Menezes M.O.T. 2012. O complexo vegetacional da zona litorânea do Ceará. Acta Botanica Brasilica, 26, 108-124

CFMV. 2002. Dispõe sobre os procedimentos e métodos de eutanásia em animais e dá outras providências. Brasília: Conselho Federal de Medicina Veterinária do Brasil (In Portuguese)

Colwell R.K. 2013. EstimateS: Statistical estimation of species richness and shared species from samples. Version 9. User's guide and application at: http://purl.oclc.org/estimates

Fellis J.K., Esch G.W. 2005. Autogenic-allogenic status affects interpond community similarity and species area relationship of macroparasites in the bluegill sunfish, Lepomis macrochirus, from a series of freshwater ponds in the Piedmont area of North Carolina. The Journal of Parasitology, 91, 1484-1496. DOI: http://dx.doi.org/10.1645/GE-451R.1

Gotelli N.J., Colwell R.K. 2001. Quantifying biodiversity: procedures and pitfalls in the measurement and comparison of species richness. Ecology Letters, 4, 379-391. DOI: 10.1046/j.1461-0248.2001.00230.x

Hammer Ø., Harper D.A.T., Ryan P.D. 2001. Past - Paleontological statistics software package for education and data analysis. Palaeontologia Electronica, 4, 1-9

Harte J., Conlisk E., Ostling A., Green J.L., Smith A.B. 2005. A theory of spatial structure in ecological communities at multiple spatial scales. Ecological Monographs, 75, 179-197

Hubbell S.P. 2001. The unified neutral theory of biodiversity and biogeography. Princeton University Press, New Jersey, 375pp

Karnoven A., Valtonen E.T. 2004. Helminth assemblages of whitefish (Coregonus lavaretus) in interconnected lakes: similarity as a function of species specific parasites and geographical sep- aration. The Journal of Parasitology, 90, 471-476. DOI: http://dx.doi.org/10.1645/GE-3099

Karnoven A., Valtonen E.T. 2009. Between-population similarity in intestinal parasite community structure of pike (Esox lucius) effects of distances and historical connections. The Journal of Parasitology, 95, 505-511. DOI: http://dx.doi.org/10.1645/GE1564.1

Keane R.M., Crawley M.J. 2002. Exotic plant invasions and the enemy release hypothesis. Trends in Ecology and Evolution, 17,164-170. DOI: http://dx.doi.org/10.1016/S01695347(02)02499-0

Krasnov B.R., Shenbrot G.I., Mouillot D., Khokhlova I.S., Poulin R. 2005. Spatial variation in species diversity and composition of flea assemblages in small mammalian hosts: geographical distance or faunal similarity? Journal of Biogeography, 32, 633644. DOI: 10.1111/j.1365-2699.2004.01206.x

Locey K.J., Stone P.A. 2006. Factors affecting range expansion in the introduced Mediterranean Gecko, Hemidactylus turcicus Journal of Herpetology, 40, 526-530. DOI: http://dx.doi.org/ 10.1670/0022-1511(2006)40[526:FAREIT]2.0.CO;2

Locke S.A., Levy M.S., Marcogliese D.J., Ackerman S., McLaughlin J.D. 2011. The decay of parasite community similarity in ring-billed gulls Larus delawarensis and other hosts. Ecography, 34, 1-9. DOI: 10.1111/j.1600-0587.2011.07244.x

Magurran A.E. 1988. Ecological diversity and its measurement. Princeton University Press, Princeton, 172pp

Menezes V.A., Vrcibradic D., Vicente J.J., Dutra G.F., Rocha C.F.D. 2004. Helminths infecting the parthenogenetic whiptail lizard Cnemidophorus nativo in a restinga habitat of Bahia state, Brazil. Journal of Helminthology, 78, 323-328. DOI: http://dx.doi.org/10.1079/JOH2004247

Nekola J.C., White P.S. 1999. The distance decay of similarity in biogeography and ecology. Journal of Biogeography, 26, 867-878. DOI: http://dx.doi.org/10.1046/j.1365-2699.1999.00305.x

Oliva M.E., González M.T. 2005. The decay of similarity over geographical distance in parasite communities of marine fishes. Journal of Biogeography, 32, 1327-1332. DOI: 10.1111/ j.1365-2699.2005.01288.x

Oliveira W.R., Frota P.V. 2011. Caracterização sócioambiental do município de Tutóia - Maranhão. Revista Geográfica de América Central, 2, 1-15

Phillips B.L., Kelehear C., Pizzatto L., Brown G.P., Barton D., Shine R. 2010.Parasites and pathogens lag behind their host during of host range advance. Ecology, 91, 872-881. DOI: http://dx.doi.org/10.1890/09-0530.1

Poulin R. 1997. Species richness of parasite assemblages: evolution and patterns. Annual Review of Ecology and Systematics, 28 , 341-358. DOI: 10.1146/annurev.ecolsys.28.1.341

Poulin R. 2003. The decay of similarity with geographic distance in parasite communities of vertebrate hosts. Journal of Biogeography, 30, 1609-1615

Poulin R., Blanar C.A., Thieltges D.W., Marcogliese D.J. 2011a. The biogeography of parasitism in sticklebacks: distance, habitat differences and the similarity in parasite occurrence and abundance. Ecography, 34, 540-551. DOI: 10.1111/j.1600-0587. 2010.06826.x

Poulin R., Krasnov B.R., Mouillot D., Thieltges D.W. 2011b. The comparative ecology and biogeography of parasites. Philosophical Transactions of The Royal Society, 366, 2379-2390. DOI: $10.1098 /$ rstb.2011.0048

Poulin R, Morand S. 1999. Geographical distances and the similarity among of parasite communities of conspecific host populations. Parasitology, 119, 369-374

R Development Core Team. 2012. R: A language and environment for statistical computing. R Foundation for Statistical Computing, Vienna, Austria 
Ricklefs R.E. 1987. Community diversity: relative roles of local and regional process. Science, 235, 167-171. DOI: 10.1126/science.235.4785.167

Rocha C.F.D., Anjos L.A. 2007. Feeding ecology of a nocturnal invasive alien lizard species, Hemidactylus mabouia Moreau De Jonnès, 1818 (Gekkonidae), living in a outcrop rocky area in southeastern Brazil. Brazilian Journal of Biology, 67, 485-491. DOI: http://dx.doi.org/10.1590/S1519-698420070 00300013

Rocha C.F.D., Anjos L.A., Bergallo H.G. 2011. Conquering Brazil: the invasion by the exotic gekkonid lizard Hemidactylus mabouia (Squamata) in Brazilian natural environments. Zoologia, 28, 747-754. DOI: http://dx.doi.org/10.1590/S198446702011000600007

Rödder D., Solé M., Böhme W. 2008. Predicting the potential distributions of two alien invasive housegeckos (Gekkonidae: Hemidactylus frenatus, Hemidactylus mabouia). North-Western Journal of Zoology, 2, 236-246

Santos-Filho F.S. 2009. Composição florística e estrutural da vegetação de restinga do estado do Piauí. PhD Thesis, Universidade Federal Rural de Pernambuco, Recife, Brazil (In Portuguese)

Received: May 21, 2015

Revised: August 24, 2015

Accepted for publication: October 8, 2015
Soininen J., McDonald R., Hillebrand H. 2007. The distance decay of similarity in ecological communities. Ecography, 30, 312. DOI: $10.1111 / j .0906-7590.2007 .04817 . x$

Thieltges E.W., Ferguson M.A.D., Jones C.S., Krakau M., Montaudouin X., Noble L.R., Reise K., Poulin R. 2009. Distance decay of similarity among parasite communities of three marine invertebrate hosts. Oecologia, 160, 163-173. DOI: http://dx.doi.org/10.1007/s00442-009-1276-2

Torchin M.E., Lafferty K.D., Dobson A.P., McKenzie V.J., Kuris A.M. 2003. Introduced species and their missing parasites. Nature, 421, 628-630. DOI: 10.1038/nature01346

Vanzolini P.E. 1978. On South American Hemidactylus. Papéis Avulsos de Zoologia, São Paulo, 31, 307-343

Vinarski M.V., Korallo N.P., Krasnov B.R., Shenbrot G.I., Poulin R. 2007. Decay of similarity of gamasid mite assemblages parasitic on Palearctic small mammals: geographic distance, hostspecies composition or environment. Journal of Biogeography, 34, 1691-1700. DOI: 10.1111/j.1365-2699.2007.01735.x

Vitt L.J. 1995. The ecology of tropical lizards in the Caatinga of Northeast of Brazil. Occasional Papers of Oklahoma Museum of Natural History, 1, 1-29 